\title{
Problem Faced by Customers While using Internet Banking, With Special Reference to SBI
}

\author{
M.P.Santhiya, R.Radhika
}

\begin{abstract}
Information Technology plays an important role in the banking sectors. Information Technology is required as a major factor to perform the banking operations more effectively and accurately. Customers are in hard settings in today's technological world. Therefore banks have to strategically pioneer things to retain their customers. Bank have expanded their services both in Brick and Mortar and also through internet. The services offered by banking sector through internet have entirely changed the life style of the customers. The services offered through internet is termed as Internet Banking. The raising trends of Internet banking raises important issues in the area of consumers banking behaviors and decisions. The purpose of this paper is to highlight the concept of Internet banking and what are the problems faced by the sbi customers in the adoption of Internet banking technology.
\end{abstract}

Keywords - Internet banking, Types, problems in usage of Internet banking.

\section{INTRODUCTION}

Indian banking sector is one of the fastest emerging sector in India. By the entry of private sector banks and foreign banks during the period of Post globalization stimulated the competition. Information technology completely changed the pictureisation of Indian banking industry. Private and foreign banks adopted new ways of delivering services to its customers. Electronic way of transactions are adopted instead of traditional banking. This was the tuff time for Indian public sector banks to maintain their customer base. To overcome this situation, RBI taken various initiatives to introduce information technology regulations for Indian banking sector and made mandatory for all the banks to adopt Internet banking. Internet banking is defined as a facility provided by banking and financial institutions which makes the user to execute banking related transactions through Internet.

The main advantage of Internet banking is the customers can execute the services sitting at home, to transact business. Due to which, the account holder need not have to personally visit the bank. Many transactions are executed by the account holder with the help of internet banking When small transactions like balance inquiry, record of recent transaction, etc. are to be processed, the Internet banking facility proves to

Revised Manuscript Received on October 25, 2019.

M.P.Santhiya ${ }^{1}$, Department of MBA, Noorul Islam Centre for Higher Education, Kumaracoil, Kanya kumari District. Tamilnadu, India,Email: sandyamadhavan@gmail.com

R.Radhika*, Department of MBA,Noorul Islam Centre for Higher Education,Kumaracoil,Thuckalay,Corresponding

Email: rdhujaasourish@gmail.com

be very handy. Thus the concept of Internet banking has made a revolutionary change in the field of banking and finance

Internet banking products and services are categorized in two terms wholesale products and services and retail / fiduciary products and services.

\section{A. Internet Banking}

Electronic Banking is a combination of two terms, Electronic technology and Banking. Electronic Banking or Internet banking is a process by which a customer performs their banking activities electronically without visiting their branch banks. E-Banking mention the provision of banking and related service through extensive use of information technology without direct recourse to the bank by the customer. Internet Banking in simple term which means, it does not involve any physical exchange of money, but everything is done electronically, from one account to another, using the internet. Internet banking is like normal banking, with one big exception. instead of visiting banks to perform transactions , the customers can access the account at any time from any part of the world and do so when they have the time, and not when the bank is open. E- banking is a virtual blessings for busy executives and home makers and no more precious time off from work to get a demand draft made or a Cheque book issued. Banks offers Internet banking facilities in two ways ,through banking websites and also offer internet banking to its customers in addition to its traditional delivery channels.

Internet banking Structure :

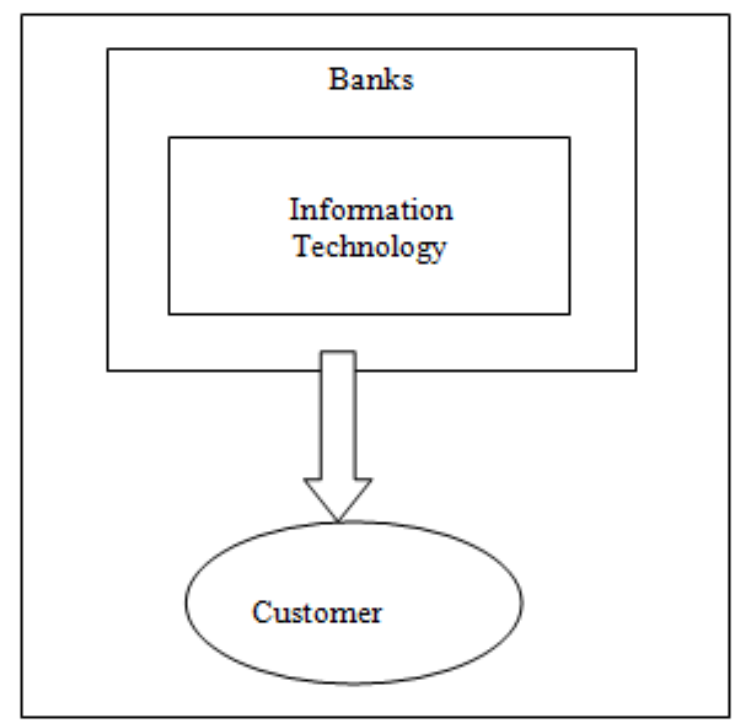




\section{Problem Faced by Customers While using Internet Banking, With Special Reference to SBI}

Products and services offered by SBI through Internet:

* Account Enquiries

* Print out of the Account statements

* Fund transferring to their own accounts

* RTGS

* NEFT

* Requesting for cheque book in online

* bill payment

* Requesting for loan through online

* ticket booking

* Tax payment

* Premium payment

Different Types Of Internet Banking :

$\checkmark$ Informational : This is the basic level of internet banking, the bank has marketing information about the products and services on their stand alone server. Here the risk is relatively low.

$\checkmark$ Communicative : In this type the internet banking system allows some interaction between customer and the bankers system, the interaction limited to electronic mail, account enquiry, loan applications etc.

$\checkmark$ Transactional : This level allows the customers to do their transactions, customers transactions include accessing accounts, paying bills, transferring funds etc.

\section{LITERATURE REVIEW}

In [1] examined Education qualification plays a major role among the customers influence the level of using Internet banking facility, customers are very well satisfied with the services provided through internet banking facility, like secrecy maintenance, account transfer, updating transactions etc. The success of Internet banking is not only depends on the technology but, to a large extent, on the attitude, commitment and involvement of the operation at all levels and how far the customers reap the benefits from Internet banking services.

In [2] The researcher highlighted the development of Internet banking in rural area. investigation is done on applications of internet banking on rural customers in rural areas, particularly towards the new generation of rural area. while comparing traditional banking with Internet banking .most of the respondents are very well satisfied with Internet banking and Internet banking provides different facilities to their customers to perform their banking activities.

In [3] stated that internet banking provides a high level of convenience to the customers to perform the activity at any time anywhere. however it continues to challenges on financial security and privacy. customers are advised not to share their personal information like pin number, account number, password with including the bank employees, proper sig in and signout should be done after completing the transaction process.

In[4] examined the benefits of e banking channels of banking customers in kottayam districts of Kerala, as per the perception of banking customers e banking builds a image in the mind of the customers to enhance their competitive position. customers are very well satisfied and benefited with the e banking services which are provided at a low cost. while comparing with traditional banking customers are more attracted with e banking services because it not only saves the time of the customers but their operating cost and sales cost.
In[5] explained the concepts and importance of $\mathrm{E}$ banking declining the cost of Internet and mobiles will definitely boom e banking in India. On the analysis the researcher concluded that emerging payment system in large value in india is RTGS and NEFT, on card payment system debit card is more popular than credit card, more number of ATMs particularly in rural areas which indicates the customers are start accepting ATM as a channel for their banking transactions.

\section{PROBLEM STATEMENT}

Internet banking has not yet become mainstream. This means that marketers in banks, financial institutions and consumer educators still have to make an effort to understand the factors which lead to the adoption of Internet banking. by the availability of review of literature the researcher stated the customers are facing problems in the usage of Internet banking and they are not adequately aware of the concept of Internet banking. Hence the aim of the study is to analyze the problem in usage of internet banking among the SBI customers.

\section{OBJECTIVE OF THE STUDY}

1.To Understand the concept of Internet banking

2. To find out the awareness about Internet banking among SBI customers.

3. To Study the problem faced by the customers in usage of Internet banking

\section{RESEARCH METHODOLOGY}

\section{A. Survey design}

The survey instrument was designed and used for data collection for this study This study used both primary and secondary data. Secondary data were collected from thesis, websites, various journals and books. Primary data is collected through structured questionnaire from the SBI customers.

\section{B. Data Collection}

Data were collected from 150 respondents who are all holding a bank account in SBI .

\section{Data Analysis and Hypothesis Testing}

Tools for Analysis :

The following statistical tools have been used for the purpose of analyzing data collected.

$$
\begin{aligned}
& \text { * Percentage analysis } \\
& \text { * Friedman's ranking analysis } \\
& \text { * T-test }
\end{aligned}
$$

\section{Percentage Analysis :}


Table 1: Demographic profile of the Respondents

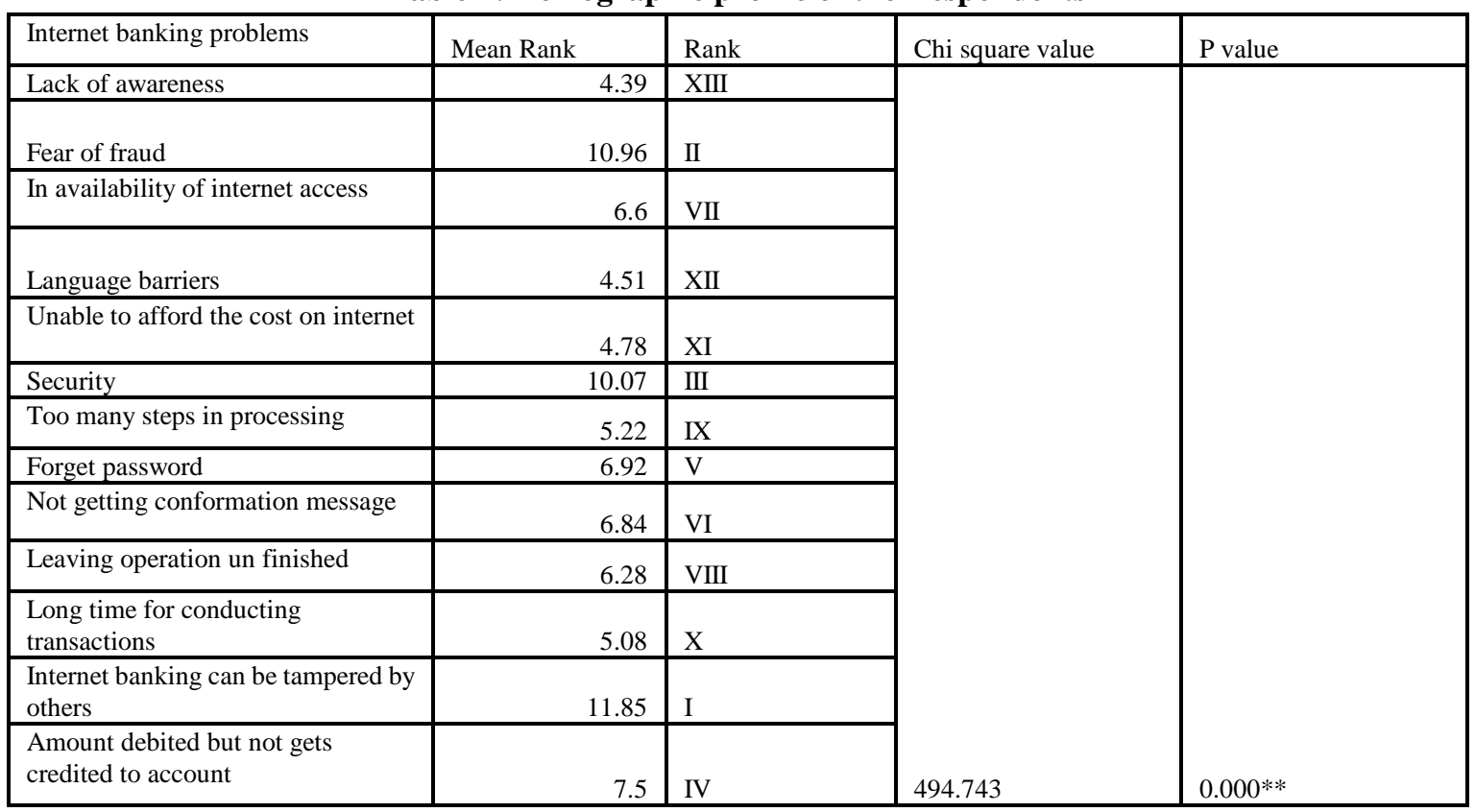

Table 3: t-test for significant difference between Gender

Source: Primary Data

It is observed from the above table that most of the respondents are belong to Male category, Majority of them are belong to the age group between 30-40years. ,Educational qualification of most of the respondents are at belong to PG degree level, majority of the respondents are employees and most of the respondents are married

2.Friedman's ranking analysis

Table 2 shows the Friedman Test for Significant

Difference among Mean Ranks towards the problems faced by the sbi customers in the usage of Internet banking . 3

\begin{tabular}{|c|c|c|c|c|c|c|}
\hline \multirow{4}{*}{$\begin{array}{l}\text { Internet } \\
\text { Banking } \\
\text { Problem }\end{array}$} & & \multirow[t]{2}{*}{$\begin{array}{l}\mathrm{t} \\
\text { Value }\end{array}$} & \multirow[t]{3}{*}{ P Value } \\
\hline & Male & & Femal & & & \\
\hline & Mean & $\mathrm{SD}$ & Mean & $\mathrm{SD}$ & & \\
\hline & 25.27 & 5.418 & 29.00 & 6.657 & -2.841 & $0.005^{* * *}$ \\
\hline
\end{tabular}

Source: Primary Data

From the Friedman's ranking analysis, Internet banking can be tampered by others is the major problems of the customers in the usage of Internet Banking, fear of fraud, security issues, amount debited but not credited to their account ,forgetting password, not getting conformation message are the other major problems faced by the customers in adoption of e-banking technology. from the above ranking problems top six problems are mentioned.

\section{T-test :}

Hypothesis I :

Null Hypothesis: There is no significant relationship among Gender and problem in usage of Internet banking facility

\begin{tabular}{|c|c|c|c|c|c|c|}
\hline \multirow{5}{*}{$\begin{array}{l}\text { Internet } \\
\text { Banking } \\
\text { Problems }\end{array}$} & \multicolumn{4}{|c|}{ Gender } & \multirow[t]{3}{*}{$\begin{array}{l}\mathrm{t} \\
\text { Value }\end{array}$} & \multirow[t]{3}{*}{ P Value } \\
\hline & \multicolumn{2}{|l|}{ Male } & \multicolumn{2}{|c|}{ Female } & & \\
\hline & Mean & SD & Mean & SD & & \\
\hline & & 5.41 & & 6.65 & -2.84 & $0.005^{*}$ \\
\hline & 25.27 & 8 & 29 & 7 & & \\
\hline
\end{tabular}

Since the $\mathrm{P}$ value is less than 0.01 .Hence the null hypothesis is rejected at $1 \%$ level with regard to the problem in usage of internet banking. so we can conclude that there is a significance relationship between gender and problem in using internet banking technology.

Hypothesis II : There is no significant relationship between Martial status and Problem in usage of Internet banking facility.

Table 4: t-test for significant relationship between Martial status and Problem in usage of Internet banking

\begin{tabular}{|c|c|c|c|c|c|c|}
\hline \multirow[b]{4}{*}{$\begin{array}{l}\text { Internet } \\
\text { banking } \\
\text { problems }\end{array}$} & \multicolumn{4}{|c|}{ Marital status } & \multirow[t]{3}{*}{$\begin{array}{l}\mathrm{T} \\
\text { value }\end{array}$} & \multirow[t]{3}{*}{$\begin{array}{l}\mathrm{P} \\
\text { value }\end{array}$} \\
\hline & \multicolumn{2}{|c|}{ married } & \multicolumn{2}{|c|}{ unmarried } & & \\
\hline & Mean & $\mathrm{SD}$ & Mean & $\mathrm{SD}$ & & \\
\hline & 26.51 & 6.145 & 25.27 & 5.275 & .861 & 0.392 \\
\hline
\end{tabular}

Source: Primary Data

Since the $\mathrm{P}$ value is greater than 0.05 .Hence the null hypothesis is accepted at 5\%level with regard to the problem in usage of internet banking. so we can conclude that there is no significance difference between Marital status and problem in usage of internet banking facility. 


\section{FINDINGS}

There is a significance difference between gender and problem in usage of internet banking, majority of the respondents are between the age group of 30-40 and educational qualification are at PG level and by the marital status majority of the respondents are married, it is to be found that majority of the customers are aware about the Internet banking technology only limited are unaware .Internet banking can be tampered by others time while making transaction was the major problem faced by majority of the customers in usage of internet banking technology .customers have a fear in security issues and they are confidence less in handling the e-banking technology. The respondents also have a feel that they have lack of knowledge in handling the Internet banking technology.

\section{SUGGESTIONS}

- The banks should strengthen their security measures to control frauds for customer safety .

- Bank should provide proper awareness to their customers about the usage of the technology by conducting awareness camps, customer care centers, etc. communication can be given through press, media, by constructing websites etc.

- Transaction cost regarding internet banking should be minimized or eliminated if it is possible, this may leads more customers to opt the technology.

\section{CONCLUSION}

Therefore this study identifies the awareness level and problem among the customers in adoption of internet banking technology. Internet banking is a great boon to the customers. All most all the banking transactions except withdrawals and deposits done through internet banking. So banks need to educate the customers that they are not technologically strong. Finally the concludes that e-banking is need of hour even though it has hurdels in its implementation process but at the same time it has a bright future in India.

\section{REFERENCES}

1. Rajesh kumar Srinivasan " Customers perception on usage of internet banking "Innovative marketing, vol 3,issue 4,2007.

2. Bhavesh and Parmar et.al,"Rural banking through Internet:A study on use of internet banking rural customers "Asian journal of management research,vol.3, issue 2,2013,pp.325-335.

3. R Shukla, "E-Banking :Problems and Prospects ", International journal of management and business,vol.1,No.1,2011,pp.23-25

4. G Ajimon and G.S.Giresh kumar, "Banking Customers perceptions on the benefits of E-banking someEmpiricalEvidence",Acumen,vol.5,no.1,2012,pp.16-21

5. Jamaluddin ,"E banking: challenges and opportunities in India", proceedings of 23rd International Business research conference 18-20,marriot Hotel Melbourne, Australia, november 2013.

6. V.Krishnamoorthy and R Srinivasan, "Internet banking as a Tool for customer relationship management-A study on customers perspective", Indian journal of research,vol.2,No.2,2013,pp.187-190.

7. [ Elavarasi and Surulivel, "Customer awareness and preference towards E-Banking services of banks-A Study of SBI",International research journal of business and management-IRJBM,vol.IV,2014,pp.59-67.

8. Khushbu Agarwal,"An Empirical Study on customer services of selected private sector banks with special reference to Udaipur city "Journal of reserach in commerce and management,vol.III,2014,PP.12-18.
9. Abbokar siddiq,"Role of technology in banking Industry-An Empirical study in India ",International conference of technology and business management, march 2015,pp.23-25

10. G.M.Maitlo "Factors that influences the adoption of online banking services in hyderabad", International journal of economics and management sciences, vol.4, No.1,2015, pp.1-10. 